\title{
Knowledge, Attitudes and Practices of Barrier Measures Related to COVID-19 among Students during Physical and Sports Education Classes in Colleges in the Republic of Benin in 2020
}

\author{
Tonon Brigitte Affidéhomé*, Tévoédjrè Doréana Frida, Gouthon Gilchrist, Gouthon Polycarpe, \\ Quenum Rostand Anaïs Sègla, Gangbo Jésutoyin Moyoriola Melchisédek, Bio Nigan Issiako
}

\section{Tonon Brigitte \\ Affidéhomé*, Tévoédjrè \\ Doréana Frida, Gouthon Gilchrist, Gouthon Polycarpe, Quenum Rostand Anaïs Sègla, Gangbo Jésutoyin Moyoriola Melchisédek, Bio Nigan Issiako}

Health and Evaluation Research Unit, National Institute of Youth, Physical Education and Sport, University of Abomey-Calavi (UAC), Porto-Novo, REPUBLIC OF BENIN.

\section{Correspondence}

\section{Dr. Brigitte A Tonon}

Sport, Health and Evaluation Research Unit. National Institute of Youth,

Physical Education and Sport,

University of Abomey-Calavi (UAC).

01 BO 169 Porto-Novo,

REPUBLIC OF BENIN.

Email: affidehome@yahoo.fr

\section{History}

- Submission Date: 12-11-2021

- Revised Date: 03-12-2021

- Accepted Date: 29-12-2021

DOI : 10.5530/ijmedph.2022.1.5

Article Available online

http://www.ijmedph.org/v12/i1

\section{Copyright}

(C) 2022 Phcog.Net. This is an openaccess article distributed under the terms of the Creative Commons Attribution 4.0 International license.

\begin{abstract}
Introduction: Coronavirus-2019 (COVID-19) was considered a pandemic by the World Health Organization (WHO) in March 2020, due to its rapid and persistent global spread. In order to combat the pandemic, the WHO has recommended barrier measures that have affected the lives of people in many countries. Objectives: The present study aims to determine the levels of knowledge, attitudes and practices related to barrier measures related to Covid-19 among secondary school students in the south of Benin during Physical and Sports Education (PSE) classes. Methods: This is a cross-sectional, descriptive and analytical study carried out among 1000 students, including 387 girls from secondary schools in the Littoral department in southern Benin, using a self-administered questionnaire. Results: The majority of the students surveyed showed average levels of knowledge (70\%) and attitudes (66.6\%) but a poor level of practice $(0.0 \%$ ) with regard to barrier measures at PSE or not. Conclusion: Awareness of the pandemic must therefore be reinforced among students in order to improve their knowledge, attitudes and practices in relation to compliance with the recommended barrier measures. This will help prevent PSE classes from spreading COVID-19 in Beninese schools.

Key words: COVID-19, CAP survey, Barrier measures, Students, Physical and Sports Education. Key message: In Benin, physical and sports education favours physical contact in its delivery, thus facilitating the risks of exposure to COVID-19.
\end{abstract}

\section{INTRODUCTION}

The world is exposed to COVID-19 since 2019 with 240 million cases recorded, ${ }^{1}$ of which 24,560 confirmed in Repubic of Benin, on 19 October 2021. ${ }^{2}$ Although the percentage of infection is lower in Africa and particularly in the Republic of Benin, Africa may present a very difficult situation, due to various co-morbidities (diabetes, obesity, malaria, hypertension and AIDS), combined with poverty and poor quality health services. ${ }^{3,4}$ In this case, there is an urgent need for people to have appropriate knowledge about the virus, behaviour and practices to control its spread. The protection of children and adolescents in secondary schools is particularly important in order to limit or prevent the spread of COVID-19 in schools, even though children and adolescents under 18 years of age represent only $8.5 \%$ of reported cases, they can act as drivers of transmission within their community. ${ }^{5}$ These children and adolescents contract a mild form of the coronavirus, but severe cases can occur especially if they have underlying conditions such as asthma, diabetes and obesity.,7 Barrier measures have been adopted to slow down and/or prevent COVID-19 spread, ${ }^{8}$ especially in educational institutions where Physical and Sports
Education (PSE) have been found to expose students to the risk of contamination. The present study aims to determine the levels of knowledge, attitudes and practices of barrier measures related to COVID-19 among students in southern Benin during PSE classes in 2020.

\section{METHODS}

This is a cross-sectional study, of a descriptive and analytical type, carried out from mid-May to mid-June 2020 with students from four Colleges of General Education (CGE) in the south of the Republic of Benin. It was carried out two weeks after the resumption of PSE classes in Benin's secondary schools and colleges after the lockdown, in the form of a Knowledge, Attitudes and Practices (KAP) questionnaire survey. The four schools and students were selected using the non-random method and respectively the reasoned choice technique (gave approval for the study) and the convenience technique. The most represented age group was $10-14$ years.
Cite this article : Tonon BA, Tévoédjrè DF, Gouthon G, Gouthon P, Quenum RAS, Gangbo JMM, Bio Nigan I. Knowledge, Attitudes and Practices of Barrier Measures Related to COVID-19 among Students during Physical and Sports Education Classes in Colleges in the Republic of Benin in 2020. Int J Med Public Health. 2022;12(1):24-7. 
The study sample consisted of 1,000 surveyed students aged 10 to 18 , of whom 613 were boys. The respondents met the following inclusion criteria: be a regularly enrolled student for the academic year 2019-2020 in one of the selected schools; be a regularly participate in PSE class after the lockdown; filled out an informed free consent form to participate in the study and to have obtained parental permission, as well as permission from the school's parent association. Participants in the study were informed of the objectives of the study, reassured that their identities would be kept confidential and that the results would only be used for research purposes.

A four-part questionnaire was used to collect information from each student about their identification, knowledge, attitudes and practices (KAP) of COVID-19 barrier measures during PSE lessons. The questionnaire was pre-tested in two colleges not involved in the survey, with 1500 students, to assess the consistency of the questions. The questionnaire was largely based on the WHO CAP survey development guide $^{9}$ and was self-administered to students by a team of interviewers familiar with such surveys.

The first part of the questionnaire asked for socio-demographic information of the participants including age, gender and parental education. The second part included ten items relating to knowledge, six for attitudes and seven for practices. The ten knowledge items explored six dimensions: origin, nature and cause of the disease; mode of transmission of the disease; symptoms of the disease; barrier measures to be respected; presence of cases of COVID-19 in the Republic of Benin; conditions for safe group physical and sports practice during the coronavirus pandemic. Attitudes towards the coronavirus were evaluated by six items addressing the following dimensions: frequent search for information on COVID-19; respect for barrier measures in life in general and during PSE lessons in particular; awareness of the high risk of contamination and of the need for instructions on COVID-19 during PSE. Practices were assessed through seven items covering the following dimensions: permanent wearing of masks and frequent disinfection and/ or washing of hands; other barrier measures related to COVID-19 in PSE classes; and use of teaching materials during the Covid-19 pandemic.

The three composite variables studied were the levels of knowledge, attitudes and practices related to COVID-19 barrier measures among students. Each item was answered as 'Good' or 'Poor'. The composite variables were all dichotomous and classified as 'high', 'medium' and 'low'. High levels of knowledge, attitudes and practices were obtained at the satisfaction of more than $80 \%$ correct answers per item; medium levels, between 60 and $80 \%$ and low, at the satisfaction of less than $60 \%$ correct answers. One point (01) is awarded for a high level of knowledge or attitudes or practices per item. Higher scores on all items indicate a high level of knowledge or attitudes or practices of COVID-19.

The recorded data were processed with Statistica software (Stat Soft, version 12). Descriptive statistics were presented as frequency and percentages (\%) for categorical variables. The proportion comparison test was used to compare girls and boys.

\section{RESULTS}

\section{Socio-demographic characteristics}

The majority of the subjects surveyed were boys (61.2\%) and the most represented age group was $10-14$ years $(72.8 \%)$. A total of $56.2 \%$ of the parents of the pupils (56.2\%) had a level of education corresponding to secondary education, followed by those who had studied in higher education, i.e. $23.4 \%$.

\section{Levels of knowledge}

On the 10 items evaluated (Table 1), the students recorded a high level of knowledge (85\%) relating to the origin and nature of the coronavirus, the mode of transmission, the most frequent symptoms, the barrier measures and the presence of Covid-19 in the Republic of Benin. They were, however, unaware of the conditions for safe physical exercise and sports during the pandemic $(0.0 \%)$ and have an average knowledge of the age groups most affected by the coronavirus (78.2\%) and the isolation of sick and contact cases of Covid-19 (77.6\%). Male students had a high level of knowledge about Covid-19 for 8 out of 10 items (80\%) compared to 6 out of $10(60 \%)$ for girls.

\section{Levels of Attitude}

Table 2 shows that on the six items evaluated, the respondents showed a high level of attitudes towards 4 (66.6\%). A medium level of attitudes was observed for the need to have a mask $(72.8 \%)$ and a low level for wearing a mask during PSE lessons (54.1\%). Female students showed a high level of attitudes for 5 out of 6 items (83.3\%) compared to 4 (66.6\%) for male students.

\section{Table 1: Levels of COVID-19 knowledge of surveyed students $(n=$} 1000).

\begin{tabular}{|c|c|c|c|c|c|c|}
\hline \multirow[b]{2}{*}{$\begin{array}{l}\text { Levels of knowledge } \\
\text { Items }\end{array}$} & \multicolumn{3}{|c|}{ Good } & \multicolumn{3}{|c|}{ Poor } \\
\hline & $\begin{array}{c}\text { TS } \\
\text { n (\%) }\end{array}$ & $\begin{array}{l}\text { Girls } \\
\text { n (\%) }\end{array}$ & $\begin{array}{c}\text { Boys } \\
\text { n } \\
(\%)\end{array}$ & $\begin{array}{c}\text { TS } \\
\text { n (\%) }\end{array}$ & $\begin{array}{l}\text { Girls } \\
\text { n (\%) }\end{array}$ & $\begin{array}{c}\text { Boys } \\
\text { n } \\
(\%)\end{array}$ \\
\hline $\begin{array}{l}\text { 1. Origin, nature and } \\
\text { cause of coronavirus }\end{array}$ & $\begin{array}{c}999 \\
(99.9)\end{array}$ & $\begin{array}{c}387 \\
(100)\end{array}$ & $\begin{array}{c}612 \\
(99.8)\end{array}$ & $\begin{array}{c}01 \\
(0.1)\end{array}$ & $\begin{array}{c}0 \\
(0.0)\end{array}$ & $\begin{array}{c}1 \\
(0.2)\end{array}$ \\
\hline $\begin{array}{l}\text { 2. Mode of transmission } \\
\text { (coughing, sneezing, } \\
\text { talking, singing or } \\
\text { breathing deeply, } \\
\text { contact with } \\
\text { contaminated surface) }\end{array}$ & $\begin{array}{c}946 \\
(94.6)\end{array}$ & $\begin{array}{c}335 \\
(88.6)\end{array}$ & $\begin{array}{c}611 \\
(99.7)\end{array}$ & $\begin{array}{c}54 \\
(5.4)\end{array}$ & $\begin{array}{c}52 \\
(11.4)\end{array}$ & $\begin{array}{c}02 \\
(0.3)\end{array}$ \\
\hline $\begin{array}{l}\text { 3. Frequent clinical } \\
\text { symptoms (fever, cough, } \\
\text { fatigue, loss of smell or } \\
\text { taste) }\end{array}$ & $\begin{array}{c}855 \\
(85.5)\end{array}$ & $\begin{array}{c}242 \\
(62.5)\end{array}$ & $\begin{array}{c}613 \\
(100)\end{array}$ & $\begin{array}{c}145 \\
(14.5)\end{array}$ & $\begin{array}{c}145 \\
(37.5)\end{array}$ & $\begin{array}{c}0 \\
(0.0)\end{array}$ \\
\hline $\begin{array}{l}\text { 4. Barrier measures to } \\
\text { be adopted (wearing } \\
\text { a mask, washing or } \\
\text { disinfecting hands, } \\
\text { distancing, isolation, etc.) }\end{array}$ & $\begin{array}{c}980 \\
(97.9)\end{array}$ & $\begin{array}{c}379 \\
(97.9)\end{array}$ & $\begin{array}{c}601 \\
(98.0)\end{array}$ & $\begin{array}{l}21 \\
(2.1)\end{array}$ & $\begin{array}{c}8 \\
(2.1)\end{array}$ & $\begin{array}{c}12 \\
(2.0)\end{array}$ \\
\hline $\begin{array}{l}\text { 5. Existence of } \\
\text { COVID-19 cases in } \\
\text { Benin }\end{array}$ & $\begin{array}{c}932 \\
(93.2)\end{array}$ & $\begin{array}{c}329 \\
(87.0)\end{array}$ & $\begin{array}{c}603 \\
(98.4)\end{array}$ & $\begin{array}{l}68 \\
(6.8)\end{array}$ & $\begin{array}{c}58 \\
(13.0)\end{array}$ & $\begin{array}{c}10 \\
(1.6)\end{array}$ \\
\hline $\begin{array}{l}\text { 6. Is it a contagious } \\
\text { disease }\end{array}$ & $\begin{array}{c}999 \\
(99.9)\end{array}$ & $\begin{array}{c}386 \\
(99.7)\end{array}$ & $\begin{array}{c}613 \\
(100)\end{array}$ & $\begin{array}{c}1 \\
(0.1)\end{array}$ & $\begin{array}{c}1 \\
(0.3)\end{array}$ & $\begin{array}{c}0 \\
(0.0)\end{array}$ \\
\hline $\begin{array}{l}\text { 7. Human organ most } \\
\text { affected by COVID-19 }\end{array}$ & $\begin{array}{c}968 \\
(96.8)\end{array}$ & $\begin{array}{c}373 \\
(96.4)\end{array}$ & $\begin{array}{c}595 \\
(97.1)\end{array}$ & $\begin{array}{c}32 \\
(3.2)\end{array}$ & $\begin{array}{c}14 \\
(3.6)\end{array}$ & $\begin{array}{c}18 \\
(2.9)\end{array}$ \\
\hline $\begin{array}{l}\text { 8. Age groups most } \\
\text { affected by COVID-19 }\end{array}$ & $\begin{array}{c}782 \\
(78.2)\end{array}$ & $\begin{array}{c}210 \\
(54.3)\end{array}$ & $\begin{array}{c}572 \\
(93.3)\end{array}$ & $\begin{array}{c}218 \\
(21.8)\end{array}$ & $\begin{array}{c}177 \\
(45.7)\end{array}$ & $\begin{array}{c}41 \\
(6.7)\end{array}$ \\
\hline $\begin{array}{l}\text { 9. Patients and Contact } \\
\text { cases of COVID-19 are } \\
\text { immediately isolated }\end{array}$ & $\begin{array}{c}776 \\
(77.6)\end{array}$ & $\begin{array}{c}198 \\
(51.2)\end{array}$ & $\begin{array}{c}473 \\
(77.2)\end{array}$ & $\begin{array}{c}224 \\
(22.4)\end{array}$ & $\begin{array}{c}189 \\
(48.8)\end{array}$ & $\begin{array}{c}140 \\
(22.8)\end{array}$ \\
\hline $\begin{array}{l}\text { 10. Conditions for } \\
\text { safe physical activity } \\
\text { and sports during } \\
\text { COVID-19 }\end{array}$ & $\begin{array}{c}00 \\
(0.0)\end{array}$ & $\begin{array}{c}00 \\
(0.0)\end{array}$ & $\begin{array}{c}00 \\
(0.0)\end{array}$ & $\begin{array}{l}1000 \\
(100)\end{array}$ & $\begin{array}{c}387 \\
(100)\end{array}$ & $\begin{array}{c}613 \\
(100)\end{array}$ \\
\hline
\end{tabular}


Table 2: Attitudes towards COVID-19 of the students surveyed $(n=1000)$.

\begin{tabular}{|c|c|c|c|c|c|c|}
\hline \multirow{2}{*}{$\begin{array}{l}\text { Levels of attitude } \\
\text { Items }\end{array}$} & \multicolumn{3}{|c|}{ Good } & \multicolumn{3}{|c|}{ Poor } \\
\hline & $\begin{array}{c}\text { TS } \\
\text { n (\%) }\end{array}$ & $\begin{array}{l}\text { Girls } \\
\text { n (\%) }\end{array}$ & $\begin{array}{l}\text { Boys } \\
\text { n (\%) }\end{array}$ & $\begin{array}{c}\text { TS } \\
\text { n (\%) }\end{array}$ & $\begin{array}{l}\text { Girls } \\
\text { n (\%) }\end{array}$ & $\begin{array}{l}\text { Boys } \\
\text { n (\%) }\end{array}$ \\
\hline 2. COVID-19 can be avoided & $980(98.0)$ & $379(97.9)$ & $601(98.1)$ & $20(2.0)$ & $8(2.1)$ & $12(1.9)$ \\
\hline 3. Need for mask(s) & $728(72.8)$ & $302(78.0)$ & $426(69.5)$ & $272(27.2)$ & $85(22.0)$ & $\begin{array}{c}187 \\
(30.5)\end{array}$ \\
\hline 4. Wearing masks during Physical and Sports Education & $541(54.1)$ & $312(80.6)$ & $229(37.4)$ & $459(45.9)$ & $75(19.4)$ & $\begin{array}{c}384 \\
(67.6)\end{array}$ \\
\hline 5. Practice of Physical and Sports Activities during the pandemic & $978(97.8)$ & $379(97.9)$ & $599(97.7)$ & $22(2.2)$ & $8(2.1)$ & $14(2.3)$ \\
\hline 6. Instructions received in relation to barrier measures during PSE classes & $1000(100.0)$ & $387(100)$ & $617(100)$ & $00(0.0)$ & $00(0.0)$ & $00(0.0)$ \\
\hline
\end{tabular}

n: sample size ; \% : percentage ; TS : total sample

Table 3: Levels of Covid-19 practices of surveyed students $(n=1000)$.

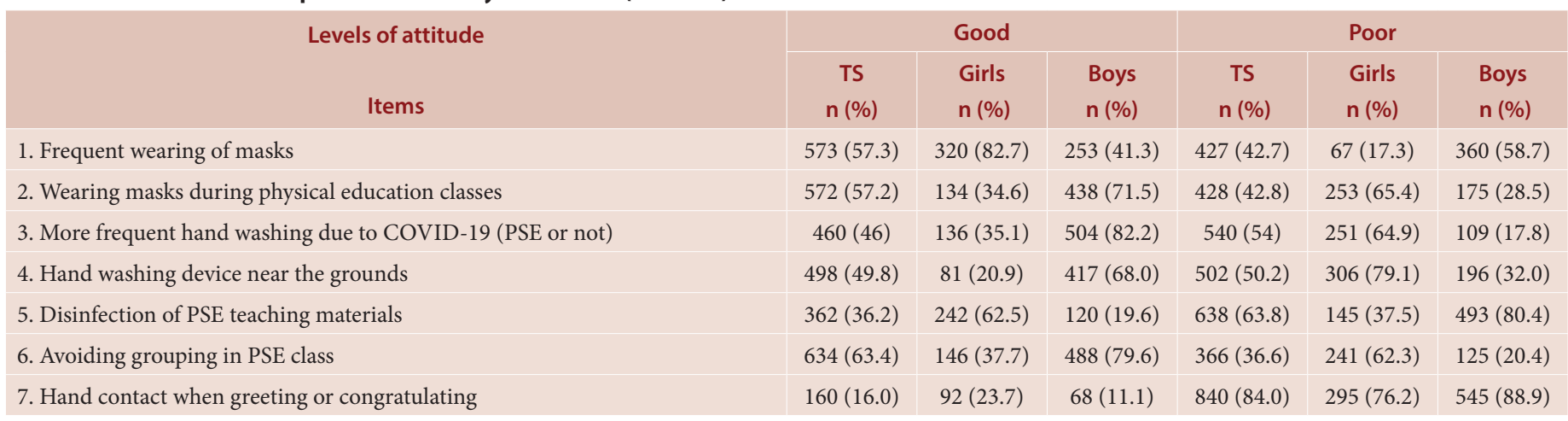

n: sample size ; \% : percentage ; TS : total sample

\section{Levels of practice}

Of the seven (07) items used to assess the level of practice of students in relation to the COVID-19 (Table 3) during PSE lessons, none had a high level of practice $(0.0 \%)$. For more than the majority of the respondents, the didactic material was not washed or disinfected (63.8\%) and physical contact to greet or congratulate each other was frequent (84\%). Female students had a high level of practice in frequently wearing masks $(82.7 \%)$ and males in frequently washing their hands (82.2\%).

\section{Levels of knowledge, attitudes and practices}

Table 4 shows that overall, the students surveyed had an average level of knowledge and attitudes about COVID-19 in PSE classes but a low level of practices regarding barrier measures. Average levels of knowledge about COVID-19 were recorded for girls (60\%) and boys (80\%), while for attitude's, female respondents had a high level (83.3\%) and boys an average level (66.6\%). Both girls and boys had a low level $(14.3 \%)$ of practices related to Covid-19.

\section{DISCUSSION}

This study aimed to determine the levels of knowledge, attitudes and practices of students regarding barrier measures in Physical and Sports Education classes during the COVID-19 epidemic in the South in the Republic of Benin. Various arrangements were made to ensure the reliability of the data collected. These included the interviewing team, which was accustomed to such surveys and maintained throughout the
Table 4: Assessment of levels of knowledge, attitudes and practices relating to the COVID-19 barrier measures $(n=1000)$.

\begin{tabular}{|c|c|c|c|}
\hline & \multicolumn{3}{|c|}{ Scores } \\
\hline Variables & Connaissances & Attitudes & Pratiques \\
\hline Total sample & $7 / 10(70 \%)$ & $4 / 6(66,66 \%)$ & $0 / 7(0.0 \%)$ \\
\hline Girls & $6 / 10(60 \%)$ & $5 / 6(83,3 \%)$ & $1 / 7(14,3 \%)$ \\
\hline Boys & $8 / 10(80 \%)$ & $4 / 6(66,66 \%)$ & $1 / 7(14,3 \%)$ \\
\hline
\end{tabular}

$\%$ : percentage.

data collection process to reduce systematic error; the questionnaire was pre-tested twice to assess the consistency of the questions and the consistency of the responses. The reliability of the data collection form was based largely on proven research on knowledge, attitudes and practices in other countries and on other topics. ${ }^{9,10}$ The operational aspects of the levels of knowledge, attitudes and practices of these students really helped to appreciate these composite variables. However, the results obtained remain valid for this population of students and the data collected could provide useful baseline information on which researchers could build to undertake an intervention study. The results showed that, in general, the participants had average levels of knowledge and attitudes about COVID-19 but practices towards the coronavirus. 
With regard to knowledge about the COVID-19, the results of the survey showed that the majority of students have an average knowledge's of barrier measures related to the coronavirus. Based on their statements, it was found that the pupils surveyed had information enabling them to identify the coronavirus in terms of its origin, symptoms, modes of transmission and barrier measures. However, they lack the knowledge to practice physical activities and sports safely during the COVID-19 period. Good levels of knowledge (84\%) about COVID-19 and barrier measures, were recorded among young people (18-39 years) in Sudan ${ }^{11}$ and Nigeria. ${ }^{12}$ In contrast, in Ethiopia, poor levels were observed in adults. ${ }^{13,14}$

In relation to attitudes, more than half of the students surveyed knew what they should do regarding barrier measures related to COVID-19. Attitudes refer to a person's behaviours in the face of a health problem ${ }^{10}$ which can be acquired as instruction through social media and other sources of information and/or through role models reflected by parents, teachers, relatives who constitute the students' immediate environment. In the current pandemic context, where the Beninese government has taken measures to curb the coronavirus in all sectors, students are predisposed to the barrier measures related to COVID-19 in educational institutions. In the school environment, these pupils, who are usually in school five times a week, will get used to the measures set out, especially during PSE classes, to better manage this health crisis. In Africa, in most of the studies on COVID-19, contradictory results have been recorded in the populations concerning attitudes. The work of Nwagbara et al. ${ }^{3}$ summarises this well.

Poor practices related to COVID-19 during PSE classes were observed among most of the students surveyed. This may be due to the fact that they have not yet found the disease an imminent threat for which they should abandon their old habits. They therefore feel that they are still out of danger and minimise the use of barrier measures in general and in PSE lessons in particular. Studies in sub-Saharan Africa have recorded poor coronavirus practices despite the relatively advanced age of the study populations compared to our own.,15

With a view to improving knowledge, attitudes and practices relating to barrier measures related to COVID-19 in PSE classes, there is an urgent need for interventions in Benin's high schools and colleges. The need to reinforce the implementation of barrier measures related to COVID-19 is of the utmost priority in order to observe a change in behaviour in the general population and especially in educational institutions. Boys appear to have a higher level of knowledge about the coronavirus and sports than girls, who have a higher level of attitudes than boys. The intervention will need to strengthen knowledge and attitude levels and improve the level of practice of barrier measures related to COVID-19 in PSE and other classes, with a view to sustainable behaviour change.

\section{CONCLUSION}

The present study conducted during the 2019-2020 school year aimed to determine the levels of knowledge's, attitudes and practices of Covid-19 related barrier measures among public school students in the littoral Department during PSE classes. The results revealed that almost all the students questioned had average levels of knowledge and attitudes but low levels of practice with regard to Covid-19-related barrier measures, especially in PSE lessons. It would seem useful for state institutions and Non-Governmental Organisations to strengthen awareness of the threat posed by this pandemic, using appropriate techniques (theatres). Students would then benefit from good knowledge, attitudes and practices relating to the mode of transmission and the barrier measures against the current pandemic. Targeted awareness raising by gender (female or male) and/ or age groups can be envisaged with larger populations in our different regions.

\section{ACKNOWLEDGEMENT}

The authors would like to thank all those who participated in this study, especially the students in the selected schools.

\section{CONFLICT OF INTEREST}

The authors declare that there is no conflict of interest.

\section{REFERENCES}

1. World Health Organization. Coronavirus (COVID-19) dashboard. WHO; 2021 [cited Oct 19, 2021]. Available from: https://covid19.who.int/.

2. World Health Organization (WHO). WHO health emergency dashboard (COVID-19). Geneva: WHO; 2021. Global. Available from: https://covid19.who. int/region/afro/country/bj [cited 6/12/2021].

3. Nwagbara UI, Osual EC, Chireshe R, Bolarinwa OA, Saeed BQ, Khuzwayo N, et al. Knowledge, attitude, perception, and preventative practices towards COVID-19 in sub-Saharan Africa: A scoping review. PLOS ONE. 2021;16(4):e0249853. doi: 10.1371/journal.pone.0249853, PMID 33872330.

4. Osseni IA. COVID-19 pandemic in sub-Saharan Africa: Preparedness, response, and hidden potentials. Trop Med Health. 2020;48(1):48. doi: 10.1186/s41182 020-00240-9. eCollection 2020. PMID 32550822.

5. Organisation Mondiale de la Santé. Questions-réponses sur les écoles et la COVID-19. Les enfants risquent-ils moins de contracter la COVID-19 que les adultes? Oms; 2021. Available from: https://www.who.int/fr/emergencies/ diseases/novel-coronavirus-2019/question-and-answers-hub/q-a-detail/q-aschools-and-covid-19 [cited 6/12/2021].

6. Trabelsi I, Briki I, Khalsi F, Belhadj I, Missaoui N, Khemiri M, et al. Asthme de l'enfant et Covid 19: Population à risque? Rev Fr Allergol. 2021;61(4). doi: 10.1016/j.reval.2021.03.173.

7. Scheen AJ. Obésité et COVID-19: Le choc fatal entre deux pandémies. Med Mal Metab. 2020;14(5):437-44. doi: 10.1016/j.mmm.2020.05.009.

8. World Health Organization. WHO Director-General's opening remarks at the media briefing on COVID19 -March 2020. WHO; 2020. Available from: https:// www.who.int/director-general/speeches/detail/who-director-general-s-openingremarks-at-the-media-briefing-on-covid-19--11-march-2020 [cited 6/12/2021].

9. World Health Organization. Advocacy, communication and social mobilization for TB control a guide to developing knowledge, attitude and practice surveys. WHO; 2008. Available from: https://apps.who.int/iris/handle/10665/43790 [cited $6 / 12 / 2021]$.

10. Essi MJ, Njoya O, L'enquête CAP. (Connaissances, Attitudes, Pratiques) en recherche médicale. Health Sci Dis. 2013;14(2):1-3. php/hsd/article/view/183.

11. Mousa KNAA, Saad MMY, Abdelghafor MTB. Knowledge, attitudes, and practices surrounding COVID-19 among Sudan citizens during the pandemic: An online cross-sectional study. SJMS. 2020;15(2):32-45.

12. Reuben RC, Danladi MMA, Saleh DA, Ejembi PE. Knowledge, attitudes and practices towards COVID19: An epidemiological survey in North-Central Nigeria. J Commun Health. 2020;2020:1-14.

13. Adhena G, Hidru HD. Knowledge, attitude, and practice of high-risk age groups to coronavirus Disease-19 prevention and control in Korem District, Tigray Ethiopia: Cross-Sectional Study. Infect Drug Resist [study]. 2020;13:3801-9. doi: 10.2147/IDR.S275168, PMID 33122925.

14. Akalu $Y$, Ayelign B, Molla MD. Knowledge, attitude and practice towards COVID-19 among chronic disease patients at Addis Zemen Hospital, Northwest, Ethiopia. Infect Drug Resist. 2020;13:1949-60. doi: 10.2147/IDR.S258736, PMID 32612371.

15. Reuben RC, Danladi MMA, Saleh DA, Ejembi PE. Knowledge, attitudes and practices towards COVID-19: An epidemiological survey in north-Central Nigeria. J Community Health. 2021;46(3):457-70. doi: 10.1007/s10900-020-00881-1, PMID 32638198. 